\title{
2-Ketogluconate Kinase from Cupriavidus necator H16: Purification, Characterization, and Exploration of Its Substrate Specificity
}

\author{
Israel Sánchez-Moreno ${ }^{1}$, Natalia Trachtmann ${ }^{2}$, Sibel Ilhan ${ }^{1,2}$, Virgil Hélaine ${ }^{1}$, \\ Marielle Lemaire ${ }^{1}$, Christine Guérard-Hélaine ${ }^{1, *}$ and Georg A. Sprenger ${ }^{2, *}$ \\ 1 Université Clermont Auvergne, CNRS, SIGMA Clermont, Institut de Chimie de Clermont-Ferrand, \\ 63000 Clermont-Ferrand, France \\ 2 University of Stuttgart, Institute of Microbiology, D-70569 Stuttgart, Germany \\ * Correspondence: christine.helaine@uca.fr (C.G.-H.); georg.sprenger@imb.uni-stuttgart.de (G.A.S.)
}

Received: 7 June 2019; Accepted: 27 June 2019; Published: 28 June 2019

\begin{abstract}
We have cloned, overexpressed, purified, and characterized a 2-ketogluconate kinase (2-dehydrogluconokinase, EC 2.7.1.13) from Cupriavidus necator (Ralstonia eutropha) H16. Exploration of its substrate specificity revealed that three ketoacids (2-keto-3-deoxy-D-gluconate, 2-keto-D-gulonate, and 2-keto-3-deoxy-D-gulonate) with structures close to the natural substrate (2-keto-D-gluconate) were successfully phosphorylated at an efficiency lower than or comparable to 2-ketogluconate, as depicted by the measured kinetic constant values. Eleven aldo and keto monosaccharides of different chain lengths and stereochemistries were also assayed but not found to be substrates. 2-ketogluconate-6-phosphate was synthesized at a preparative scale and was fully characterized for the first time.
\end{abstract}

Keywords: 2-ketogluconate; 2-ketogluconate kinase; 2-ketogulonate; 2-keto-3-deoxygluconate; Cupriavidus necator; biocatalysis; monosaccharides phosphate

\section{Introduction}

Rare ketoses have great potential, for instance, as chiral auxiliaries, as sweeteners, or (thanks to their biological properties) in pharmaceutical chemistry [1]. Among them, phosphorylated monosaccharides are of particular interest due to their central role in metabolic pathways [2,3]. Sugar phosphates, having a 2-keto functionality, can be produced by lyases or transferases. More precisely, they can be obtained by a variety of aldolases [4-9], a transaldolase [10], or a transketolase [5,11-17]. In vivo, phosphorylated monosaccharides are often obtained by direct phosphorylation of the corresponding monosaccharide, catalyzed by an ATP-dependent kinase. Such enzymes have also been efficiently applied for natural or unusual phosphorylated sugar preparation [2,3]. Kinases, as biocatalysts for the production of rare 2-ketoaldonate-phosphates, could also play a key role in the synthetic design of new biologically interesting compounds and enrich the arsenal of biocatalyst compounds. We turned to a bacterial 2-ketogluconate kinase (KGUK; EC 2.7.1.13.) as another and somewhat neglected biocatalyst for the formation of 2-ketoaldonate-6-phosphates. While chemical preparation of 2-ketogluconate-6-phosphate (KGP) has been described by vanadate/ $\mathrm{NaClO}_{3}$-catalyzed synthesis [18], an enzymatic approach would be of interest, as nontoxic substances are used, and furthermore, it is done in sustainable conditions.

KGUK is involved in the glucose and 2-ketogluconate catabolism of several aerobic bacteria, but relatively few bacterial species are able to utilize 2-ketogluconate as the sole carbon source for growth and energy provision. Besides one Gram-positive Leuconostoc mesenteroides [19], the main 2-ketogluconate utilizers are Gram-negative proteobacteria such as Pseudomonas, Aerobacter/Enterobacter/Klebsiella, or 
Ralstonia/Cupriavidus species. These bacteria may grow directly on 2-ketogluconate, which is taken up by a specific transport system (KGUT) [20]. Intracellularly, the compound may then either be reduced to gluconate [21,22] or phosphorylated by an ATP-dependent 2-ketogluconate 6-kinase, KGUK [19,23-27] (Figure 1). Some aerobic bacteria such as Pseudomonas putida, Pseudomonas aeruginosa, or Aerobacter (now classified as either Enterobacter or Klebsiella) are able to convert glucose first to gluconate and subsequently to 2-ketogluconate by periplasmic PQQ-dependent dehydrogenases. 2-ketogluconate-6-phosphate is reduced to gluconate-6-phosphate and is then either degraded via the hexose monophosphate/pentose phosphate pathway or the Entner-Doudoroff (KDPG) pathway [20,26,28-31].<smiles>O=C(O)C(=O)C(O)[C@H](O)[C@H](O)CO</smiles>

2-keto-D-gluconate (KG)
2-Ketogluconate kinase (KGUK)

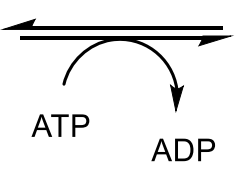

ADP

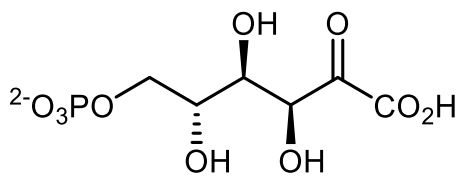

2-keto-D-gluconate-6-phosphate (KGP)

Figure 1. Reaction catalyzed by 2-ketogluconate kinase (KGUK).

2-ketogluconate kinase was first discovered as an inducible activity in 1953 in Aerobacter cloacae [32] and then in Pseudomonas fluorescens [24]. The enzyme's product, 2-ketogluconate-6-phosphate, was isolated and described at the same time [23]. Later, four other KGUKs were identified from: (i) the Gram-positive L. mesenteroides [19], (ii) Aerobacter aerogenes (nowadays classified as Klebsiella pneumoniae) [25], (iii) Hydrogenomonas eutropha H16 (newer and alternative designations are Ralstonia eutropha $\mathrm{H} 16$ or Cupriavidus necator H16) [33], and (iv) P. aeruginosa [20,28]. To the best of our knowledge, however, no studies on the substrate specificity of any bacterial KGUK have been published so far. We focused our attention on the kinase from $C$. necator, the complete genome sequence of which has been published [34], and we abbreviated this enzyme as $\mathrm{KGUK}_{\mathrm{Cnec}}$. In this work, we cloned, overexpressed, and purified the recombinant N-terminal his-tagged 2-ketogluconate kinase from C. necator $\left(\mathrm{KGUK}_{\mathrm{Cnec}}\right)$ in Escherichia coli. For the first time, its substrate specificity was studied with different commercially available sugars and with various synthetic analogues of the natural substrate 2-ketogluconate. Finally, a preparative scale of the 2-ketogluconate-6-phosphate was performed to demonstrate the synthetic potential of this enzyme.

\section{Results and Discussion}

\subsection{Cloning, Overexpression, Purification, and Characterization of KGUK from C. necator}

The $k g u K$ gene from C. necator strain H16 was cloned by PCR amplification from chromosomal DNA. The protein matched the expected molecular weight of the cloned his-tagged KGUK $\mathrm{Knec}$ $(35.7 \mathrm{kDa})$. The analysis of the cell-free extract (CFE) showed good recombinant enzyme production (4800 U per liter) in the soluble fraction. Thanks to its attached 6-histidines tag, the enzyme could be easily purified by Immobilized Metal Affinity Chromatography (IMAC). Starting from $200 \mathrm{~mL}$ of expression cell culture ( $0.85 \mathrm{~g}$ of wet weight of cells after sedimentation), $20 \mathrm{~mL}$ of CFE were obtained $\left(260 \mathrm{mg}\right.$ of protein with a specific activity of $\left.0.38 \mathrm{U} \cdot \mathrm{mg}^{-1}\right)$. After IMAC purification, $4.7 \mathrm{mg}$ of protein were obtained with a specific activity of $8.7 \mathrm{U} \cdot \mathrm{mg}^{-1}$ (Table 1). Final yield of this purification method was $42 \%$ and the purification fold was increased to 22.8 . The effect of imidazole from IMAC fractions on $\mathrm{KGUK}_{\mathrm{Cnec}}$ activity was evaluated. No activity differences were detected in samples before and after imidazole removal. Actually, imidazole displayed stabilizing properties in the $\mathrm{KGUK}_{C n e c}$ activity during storage. Indeed, purified enzymes stored at $4{ }^{\circ} \mathrm{C}$ in the presence of $0.25 \mathrm{M}$ of imidazole retained $90 \%$ of initial activity after one month, whereas protein samples in the absence of imidazole were totally inactive after only one night stored at $4{ }^{\circ} \mathrm{C}$. The addition of possible stabilizers other than imidazole, 
such as BSA or glycerol, did not increase the stability. The effects of protein freezing and freeze-drying were also unsuccessful on enzyme stabilization. Consequently, IMAC fractions were directly stored after protein purification and imidazole was removed just before each experiment in order to avoid possible chemical interferences. No loss of activity was detected after the desalting procedure, so the specific activity of the final imidazole-free fraction remained the same after IMAC purification.

Table 1. Summary of recombinant $\mathrm{KGUK}_{\text {cnec }}$ purification (from $20 \mathrm{~mL}$ of cell-free extract (CFE)).

\begin{tabular}{cccccccc}
\hline Sample & $\begin{array}{c}\text { Activity } \\
(\mathbf{U})\end{array}$ & $\begin{array}{c}\text { Protein } \\
(\mathbf{m g} / \mathbf{m L})\end{array}$ & $\begin{array}{c}\text { Volume } \\
(\mathbf{m L})\end{array}$ & $\begin{array}{c}\text { Activity } \\
\mathbf{( U / m g )}\end{array}$ & $\begin{array}{c}\text { Fold } \\
\text { Purification }\end{array}$ & $\begin{array}{c}\text { Recovery } \\
\mathbf{( \% )}\end{array}$ \\
\hline $\mathbf{1}$ & CFE & 96.0 & 13.02 & 20 & 0.38 & - & 100 \\
$\mathbf{2}$ & IMAC & 40.4 & 0.47 & 10 & 8.70 & 22.8 & 42 \\
\hline
\end{tabular}

\subsection{Enzyme Activity}

The gene $\mathrm{kguK}$ from C. necator (NCBI Reference Sequence: YP_841324.1) encodes a putative 2-ketogluconate kinase enzyme (EC 2.7.1.13) in line with earlier biochemical work which had discovered such enzyme activity in the strain H16 (formerly termed Hydrogenomonas) [33]. 2-ketogluconate kinase activity was experimentally confirmed in the recombinant KGUK samples from IMAC purification, which showed a specific activity of $8.7 \mathrm{U} / \mathrm{mg}$. Maximal enzyme activity was observed when a concentration of $1.25 \mathrm{mM}$ of 2-keto-D-gluconate (KG) was employed in the activity assay. When the KG concentration was increased, a slow and continuous drop of the activity was observed (Figure 2A).

In addition, the effect of the ATP concentration on the enzyme activity was also examined. Maximum specific activity was found at ATP concentrations of $1.25 \mathrm{mM}$. However, when the concentration was increased over $5 \mathrm{mM}$, the enzyme activity drastically decreased, showing strong inhibition by substrate excess (Figure 3B). Kinase activity showed the $\mathrm{Mg}^{2+}$ requirement as an enzyme cofactor. As the real donor phosphate substrate is the complex Mg-ATP, it is crucial to use at least the same concentrations of $\mathrm{Mg}^{2+}$ as the ATP ones, in order to ensure the right enzyme activity in the assayed conditions. The maximal enzyme activity was found at $\mathrm{Mg}^{2+}$ concentrations of $5 \mathrm{mM}$ when $1.25 \mathrm{mM}$ of ATP was employed. This enzyme displayed a similar specific activity to that of the only one described from A. aerogenes $(8.1 \mathrm{U} / \mathrm{mg})$ [25]. 

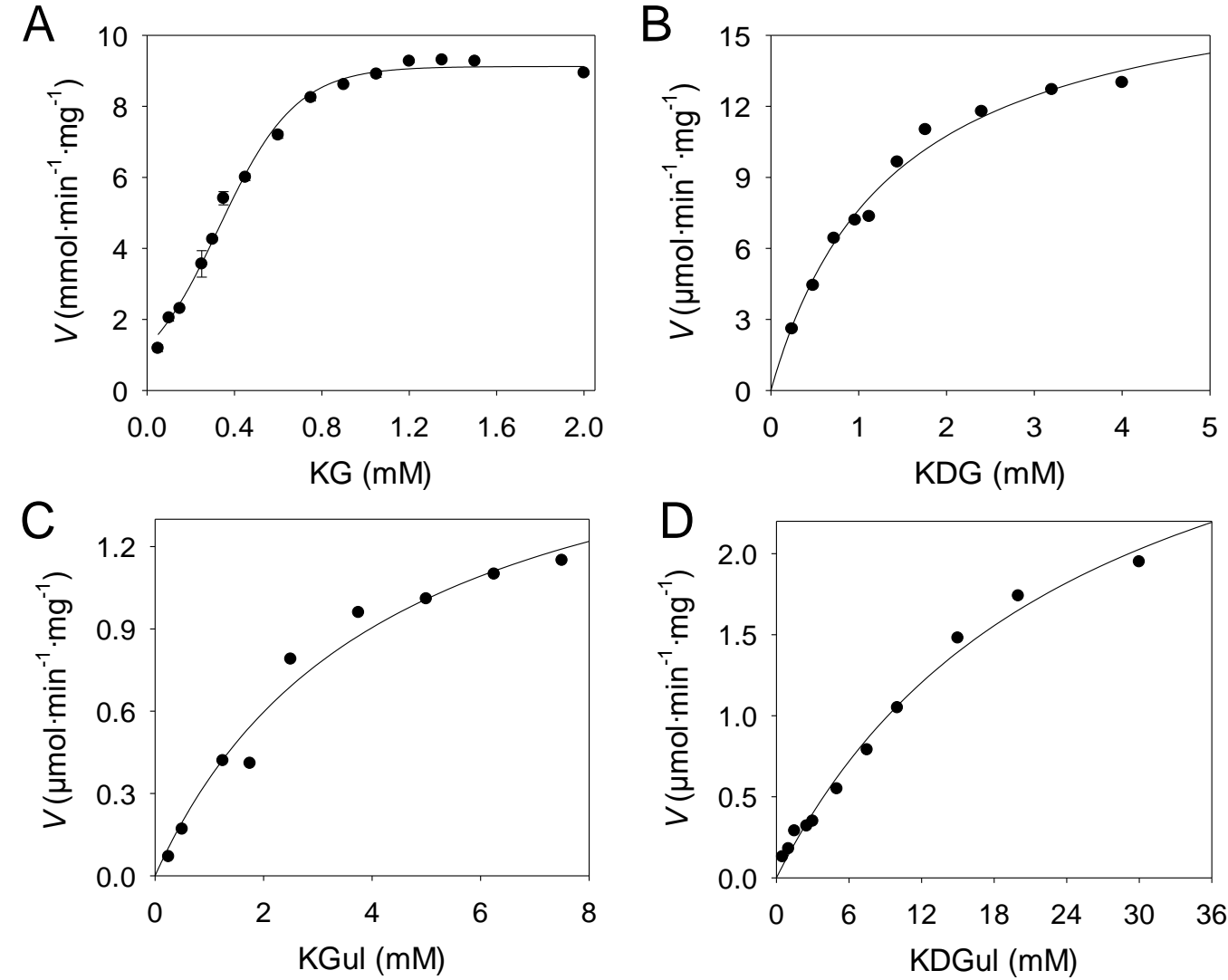

Figure 2. Substrate kinetics of kinase activity for KGUK from C. necator for different substrates (at $25^{\circ} \mathrm{C}$ ). Activity of purified KGUK was measured at increasing concentrations of the acceptor substrates 2-keto-D-gluconate (KG) (A), 2-keto-3-deoxygluconate (KDG) (B), 2-ketogulonate (KGul) (C), and 2-keto-3-deoxygulonate (KDGul) (D), maintaining a constant excess of ATP (1.25 mM) and $\mathrm{Mg}^{2+}$ (5 mM). Final concentration of pure KGUK was customized in each kinetic experiment to optimize the activity measurement: $2.5 \mu \mathrm{g} / \mathrm{mL}$ of purified enzyme for KG kinetics (A), $1.5 \mu \mathrm{g} / \mathrm{mL}$ for KDG assays (B), and $3.4 \mu \mathrm{g} / \mathrm{mL}$ for KGul and KDGul experiments (C and D).

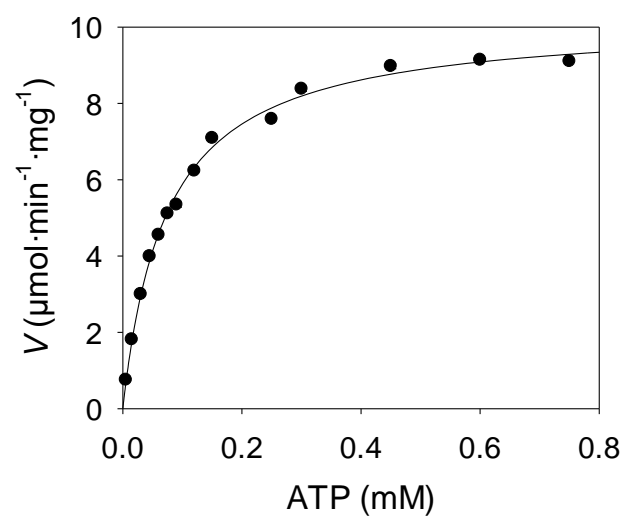

A

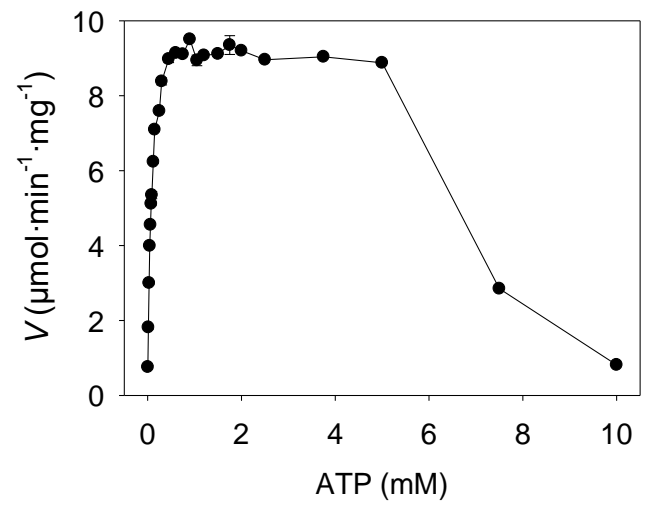

B

Figure 3. Kinase activity of the purified KGUK from C. necator was measured at increasing concentrations of ATP, maintaining a constant excess of KG $(1.25 \mathrm{mM})$ as the phosphate acceptor and $2.1 \mu \mathrm{g} / \mathrm{mL}$ of purified enzyme. ATP kinetics were carried out for kinetic constants calculation using a $\mathrm{Mg}^{2+}$ excess concentration of $5 \mathrm{mM}$ (A). To evaluate the effect of higher concentrations of ATP on the enzyme activity, additional assays were performed increasing the $\mathrm{Mg}^{2+}$ concentration to $25 \mathrm{mM}(\mathbf{B})$. When ATP concentrations over $5 \mathrm{mM}$ were used, a strong decrease in the kinase activity was observed. 


\subsection{Substrate Specificity}

Substrate specificity of the KGUK from C. necator for the phosphate acceptors was studied on a broad variety of sugars with different chemical structures. Firstly, 11 commercially available aldo and keto sugars were tested: D-glucose, L-glucose, D-fructose, D-psicose, D-tagatose, D-ribulose, D-xylulose, D-sorbose, L-sorbose, D-erythrose, and 2-deoxy-D-ribose, where both chain length and stereochemistry were varied. These compounds were reacted with KGUK and reaction progress was followed by the described spectrometric assay to assess enzyme activity (See Materials and Methods section). None of the 11 selected sugars showed any conversion, revealing they are not substrates for $\mathrm{KGUK}_{\text {Cnec }}$ in our experimental conditions.

The study was then focused on substrates with closer chemical structures to the natural KG (i.e., KGul and KGal). In addition, KGUK specificity for 3-deoxy analogues was also examined (Figure 4). Indeed, $\mathrm{KGUK}_{\mathrm{Cnec}}$ displayed some amino acid sequence identity with previously described 2-keto-3-deoxy-D-gluconate kinases (KDGK) belonging to a different kinase family (EC 2.7.1.45) (Figure 5).<smiles>O=C(O)C(=O)C(O)C(O)C(O)CO</smiles>

\section{2-keto-D-gluconate}

(KG)<smiles>O=C(O)C(=O)C(O)C(O)C(O)CO</smiles><smiles>O=C(O)C(=O)C(O)C(O)C(O)CO</smiles>

\section{2-keto-D-gulonate 2-keto-D-galactonate \\ (KGul) \\ (KGal)}<smiles>O=C(O)C(=O)C(O)C(O)CO</smiles><smiles>O=C(O)C[C@H](O)C(O)CO</smiles>

\section{2-keto-3-deoxy-D-gluconate} (KDG)

\section{2-keto-3-deoxy-D-gulonate \\ (KDGul)}

Figure 4. 2-keto-carboxylic acid sugars tested as $\mathrm{KGUK}_{\mathrm{Cnec}}$ substrate. 
A

1. MStdLDVVtL GEAMLMLVAG EAgPLEGAQt FHKRTAGA

2. M---LEVVTA GEPIVALVPQ EPGHLRGKRL LEVYVGGAEV NVAVALARLG

1. LKVGWASRLG DDSMARYLLG EMQREGVDCS QVVCEPGERT GFQFKGRVDD

2. VKVGFVGRVG EDELGAMVEE RLRAEGVDLT HFRRAPGF-T GLYLREYLPL

1. GSDPPVEYTHR RGSAASRMNP EHLDGRWLRR SRHLHVTG

2. GQGR-VFYY KGSAGSALAP GAFDPDYLEG VRFLHLSGIT PALSPEARAF 103105

1. TRQAIATMQA AGRTISEDPN LRPTLWASPE LMRETLNDLA QQCDWVLPGI

2. SLWAMEEAKR RGVRVSLDVN YRQTLWP-PE EARGFLERAL PGVDLLFLSE

1. EEGRFLTGHA EPERIAAFYR ARGARLVVVK LGADGA--YF DGEAGTGHVE

2. EEAELLFG-- ---RVEEALR ALSAPEVVLK RGAKGAWAFV DGRRAEGS--

1. AFSVEHVVDT VGGAGDGAVG VISALLEGRP VRDAVRRGAW IGARAVQVRG

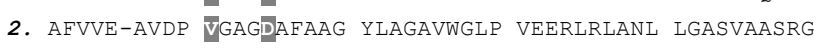

1. DTEGLPTHAQ L-----AAAS L--

2. DHegapyred LeVllKatqt FmR
B

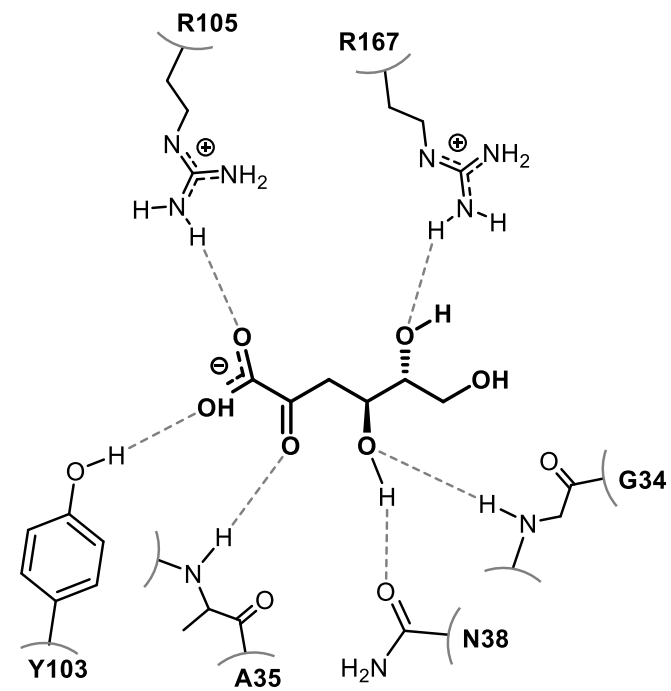

Figure 5. Sequence alignments and substrate accommodations of the concerned residues. (A) Amino acid sequence alignments of KGUK from C. necator (1.) and 2-keto-3-deoxy-D-gluconate kinase (KDGK) from Thermus thermophilus (2.). Grey-shaded amino acids have been identified as active site residues in the crystallographic structure of the KDGK enzyme. Only three residues (shaded in black) are different in the C. necator enzyme. (B) Structure of the active site of KDGK from T. thermophilus.

Thus, KDGK from Thermus thermophilus displayed 35.9\% amino acid sequence identity with the KGUK from C. necator. KDGK catalyzes the ATP-dependent phosphorylation of KDG (Figure 6), with KDG being the $\mathrm{C} 3$ deoxy analogue of KG. Enzymes from this family were also described to be able to catalyze the phosphorylation reaction of KG $[35,36]$. Nevertheless, there are no data in the literature about KDG as a substrate of KGUKs, so we decided to explore the $\mathrm{KGUK}_{\text {Cnec }}$ activity also using KDG and a $\mathrm{C} 4$ epimer (KDGul) as substrates.

KGul, KGal, and KDGul were prepared as recently published [37] by using pyruvate aldolases discovered from biodiversity. They were found to be able to use hydroxypyruvate and D-glyceraldehyde as nucleophile and electrophile substrates, respectively. In order to evaluate the catalytic properties of the $\mathrm{KGUK}_{\text {Cnec }}$ toward the five obtained compounds (Figure 4), the kinetic parameters of the enzyme were calculated (Figure 2B-D). Kinetic parameters for the donor substrate ATP were evaluated as well, and the results are summarized in Table 2.<smiles>O=C(O)CC(O)[C@H](O)CO</smiles>

2-keto-3-deoxy-D-gluconate (KDG)
2-Keto-3-deoxy-D-gluconate kinase (KDGK)

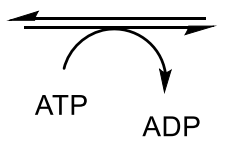

2-keto-3-deoxy-D-gluconate-6-phosphate (KDGP)

Figure 6. Reaction catalyzed by the KDGK enzymes. 
Table 2. Kinetic constants of the recombinant $\mathrm{KGUK}_{\text {cnec }}$.

\begin{tabular}{cccccc}
\hline Entry & Substrate & $\mathbf{V}_{\max }(\mathbf{U} / \mathbf{m g})$ & $\boldsymbol{k}_{\text {cat }}\left(\mathbf{s}^{\mathbf{- 1}}\right)$ & $\mathbf{K}_{\mathbf{M}}(\mathbf{m M})$ & $\boldsymbol{k}_{\text {cat }} / \mathbf{K}_{\mathbf{M}}\left(\mathbf{s}^{\mathbf{- 1}} \mathbf{M}^{-\mathbf{1}}\right)$ \\
\hline $\mathbf{1}$ & $\mathbf{A T P}$ & $10.2 \pm 0.1$ & $5.71 \pm 0.05$ & $0.073 \pm 0.002$ & $78,220 \pm 2500$ \\
$\mathbf{2}$ & $\mathbf{K G}^{\mathbf{1}}$ & $10.4 \pm 0.4$ & $5.8 \pm 0.2$ & $0.35 \pm 0.03$ & $16,770 \pm 1300$ \\
$\mathbf{3}$ & $\mathbf{K G u l}$ & $1.9 \pm 0.2$ & $1.1 \pm 0.1$ & $4 \pm 1$ & $246 \pm 70$ \\
$\mathbf{4}$ & $\mathbf{K D G}$ & $18.2 \pm 0.9$ & $10.2 \pm 0.5$ & $1.4 \pm 0.2$ & $7370 \pm 970$ \\
$\mathbf{5}$ & KDGul & $3.7 \pm 0.4$ & $2.1 \pm 0.2$ & $25 \pm 4$ & $83 \pm 20$ \\
$\mathbf{6}$ & KGal $^{*}$ & - & - & - & - \\
\hline
\end{tabular}

${ }^{1}$ KG substrate showed a sigmoid kinetics (see Figure 2A). Kinetic parameters were calculated by nonlinear regression in the Hill equation. Hill coefficient $(n)=1.4 ; K_{M}=K_{0.5} \cdot{ }^{*} \mathrm{KGal}$ was not found to be a KGUK substrate under our assay condition.

The kinetic parameters showed that KDG is a substrate of KGUK but with less efficiency than KG $\left(k_{\text {cat }} / K_{\mathrm{M}}=7370\right.$ and $16,770 \mathrm{~s}^{-1} \mathrm{M}^{-1}$, respectively). This was the opposite of what was observed in the KDGK enzymes: Kinase activity using both KDG and KG as substrates has been described in KDGKs from Sulfolobus tokodaii and T. thermophilus and, in both cases, KDG was the best substrate, whereas KG phosphorylation was less efficient [35,36]. KGul and KDGul were found as new substrates for KGUK $_{C n e c}$, although they were converted with lower catalytic efficiencies than KG and KDG. On the other hand, KGal gave no reaction. $K G$ appeared clearly as the best substrate $\left(k_{\text {cat }} / K_{M}=16,770 \mathrm{~s}^{-1} \cdot \mathrm{M}^{-1}\right)$, whereas its epimer on C3 and C4 (KGul) reacted 60-fold slower $\left(k_{\text {cat }} / K_{\mathrm{M}}=246 \mathrm{~s}^{-1} \cdot \mathrm{M}^{-1}\right)$, revealing the importance of the stereochemistry $(3 S, 4 R)$ within the active site. When a hydroxy group in $\mathrm{C} 3$ was missing (KDG), the enzyme maintained good efficiency, as evidenced by the decrease of only a half order of magnitude $\left(k_{\mathrm{cat}} / \mathrm{K}_{\mathrm{M}}=7370 \mathrm{~s}^{-1} \cdot \mathrm{M}^{-1}\right)$. Nevertheless, without a hydroxy moiety in the third position, as well as using the epimer of KDG in C4 (KDGul), a drastic decrease in efficiency $\left(k_{\text {cat }} / \mathrm{K}_{\mathrm{M}}=83 \mathrm{~s}^{-1} \cdot \mathrm{M}^{-1}\right)$ was observed. Thus, configuration in $\mathrm{C} 4$ seems to be very important for KGUK activity.

\subsection{Synthesis of 2-ketogluconate-6-phosphate}

KGUK $_{\text {Cnec }}$ was used as a biocatalyst to prepare KGP at a preparative scale as the key product for metabolic studies. Thus, a biocatalytic system based on phosphorylation of KG with this new enzyme was developed. The reaction was first assayed on a small scale in order to find out the optimal conditions. An ATP regeneration system based on phosphoenolpyruvate (PEP)/pyruvate kinase (PK) system was implemented (Figure 7B) to avoid both the difficulty in separating ADP from KGP and to circumvent inhibition by ATP at [ATP] $>5 \mathrm{mM}$ (Figure 3B). Indeed, the PEP/PK regeneration system has been proved to be compatible with a one-step purification of phosphorylated sugars via their precipitation as $\mathrm{Ba}^{2+}$ salts [7]. Reaction progress was monitored by measuring pyruvate formation during ATP regeneration. The reaction was optimized by varying the concentrations of KG and PEP in Tris- $\mathrm{HCl}$ buffer $(1.0 \mathrm{~mL}, 50 \mathrm{mM}, \mathrm{pH} 8.0)$, containing catalytic amounts of ATP (2.5 mM) and $\mathrm{MgSO}_{4}$ $(4 \mathrm{mM})$, in the presence of $\mathrm{KGUK}_{\mathrm{Cnec}}(0.35 \mathrm{U})$ and PK $(1.7 \mathrm{U}) . \mathrm{KG}$ and PEP were used in a maximum concentration of $50 \mathrm{mM}$. 
A

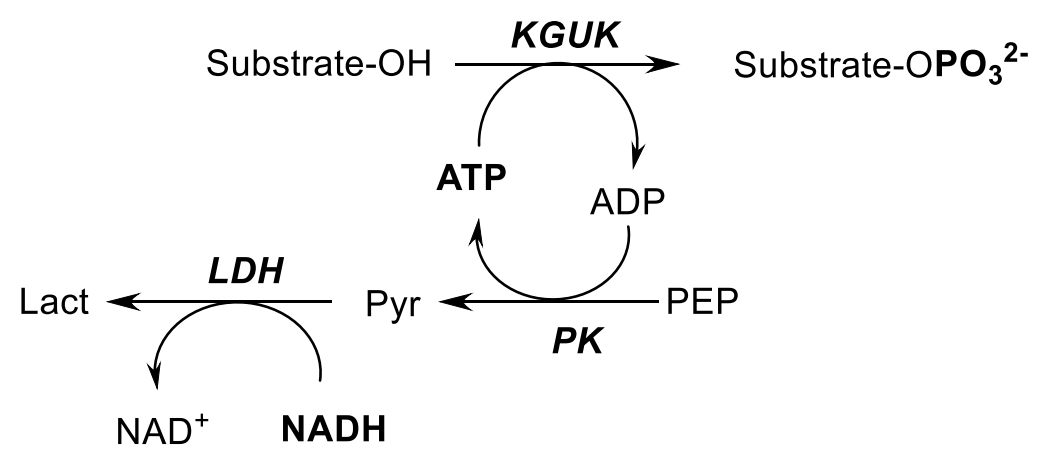

B<smiles>O=C([O-])C(=O)C(O)C(O)[C@H](O)CO</smiles>

2-ketogluconate kinase (KGUK)<smiles>CC(=O)C(=O)[O-]</smiles><smiles>C1CCCCC1</smiles>

2-keto-D-gluconate ADP

pyruvate<smiles>[R6]OC[C@@H](O)[C@H](O)[C@H](O)C(=O)C(=O)[O-]</smiles>

2-keto-D-gluconate-6-phosphate PK<smiles>C=C(O[Na])C(=O)[O-]</smiles>

PEP

Figure 7. Phosphorylation reactions: analytical (assay) and practical (synthesis) scale. (A) KGUK activity assay. Substrate phosphorylation was measured with a coupled enzymatic system, where the decrease of NADH absorbance at $340 \mathrm{~nm}$ was directly proportional to substrate phosphorylation. PK: pyruvate kinase, PEP: phosphoenolpyruvate, pyr: pyruvate, lact: lactate, LDH: lactate dehydrogenase. (B) Biocatalytic orthogonal cascade for the synthesis of 2-ketogluconate-6-phosphate (KGP).

Four different KG/PEP substrate ratios were assayed for determining the optimal concentrations. PEP was used as either the limiting substrate (KG/PEP: 1.0/0.5, 1.0/0.7, and 1.0/0.9) or in excess (KG/PEP: 1.0/1.1). In all cases, final KGP accumulation was lower than $70 \%$. The best yield (Figure 8A) was obtained with 1.0/0.5 as the KG/PEP ratio (70\% of KGP accumulated after $3 \mathrm{~h}$ of reaction). Optimization reactions were continued by increasing the final volume $(2 \mathrm{~mL})$ and decreasing the concentration of the limiting substrate $(20 \mathrm{mM})$. In these new conditions, the best results (Figure $8 \mathrm{~B}$ ) were found with a KG/PEP ratio of 1.0/0.7 ( $80 \%$ of KGP accumulation after $6 \mathrm{~h}$ ). Due to the positive effect observed during dilution, a third reaction was finally implemented in a final volume of $2.5 \mathrm{~mL}$ with $14 \mathrm{mM}$ of KG and a KG/PEP ratio of 1.0/0.8. The reaction was performed at room temperature and, under these latter conditions, the phosphorylated compound accumulation in the reaction media reached 100\% (Figure 8C) after overnight gentle stirring (100-200 rpm) (approx. $12 \mathrm{~h}$ ).

Thus, KGP could be obtained in $85 \%$ yield of pure barium salt product, corresponding to a $0.6 \mathrm{~g}$ scale. A single precipitation of KGP directly from the reaction mixture as its barium salt led to pure KGP, as depicted by the ${ }^{1} \mathrm{H}$ as well as ${ }^{13} \mathrm{C}$ NMR spectra available in the Materials and Methods section. Importantly, 2-ketogluconate-6-phosphate was for the first time fully characterized. Indeed, although this biocatalytic approach had previously been used for KGP synthesis $[23,25]$, this product was only identified by TLC then. 
A

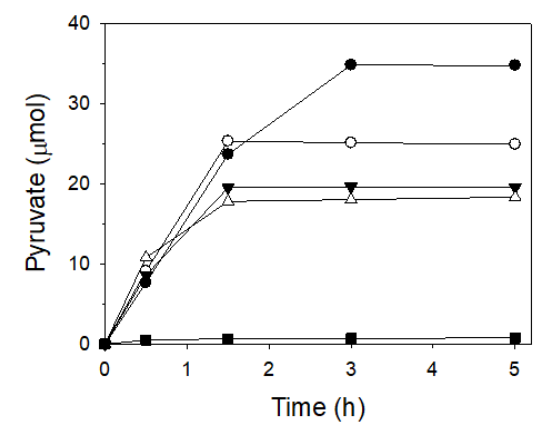

B

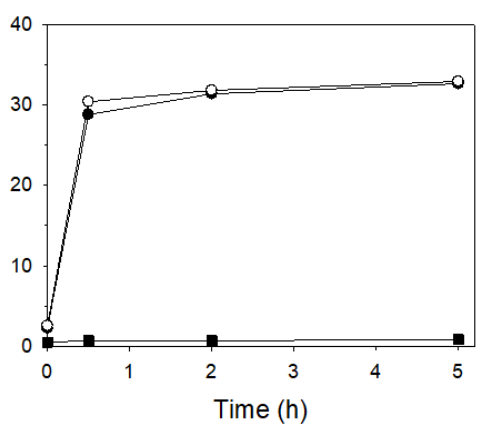

\section{C}

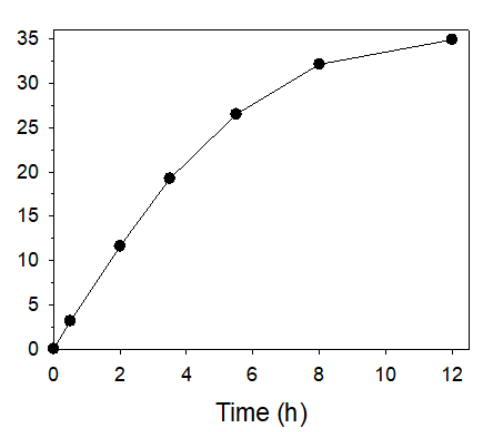

Figure 8. Optimization of the KG/PEP ratio in different $K G$ phosphorylation reactions with ATP regeneration. (A) Reactions were performed in $1 \mathrm{~mL}$ of Tris- $\mathrm{HCl}$ buffer $50 \mathrm{mM}$ and $50 \mu \mathrm{mol}$ of the limiting substrate at different ratios of KG/PEP $(1.0 / 0.5(\bullet), 1.0 / 0.7(\bigcirc)$, and 1.0/0.9 ( $\mathbf{v}), 1.0 / 1.1(\Delta))$ and a control reaction with no ATP (घ). (B) Reactions were performed in $2 \mathrm{~mL}$ of Tris- $\mathrm{HCl}$ buffer $50 \mathrm{mM}$ and $40 \mu \mathrm{mol}$ of the limiting substrate at different ratios of KG/PEP $(1.0 / 0.5(\bullet)$ and 1.0/0.7 (○)) and a control reaction with no ATP ( $\square$ ). (C) Reactions were performed in $2.5 \mathrm{~mL}$ of Tris- $\mathrm{HCl}$ buffer $50 \mathrm{mM}$ and $35 \mu \mathrm{mol}$ of the limiting substrate employing a KG/PEP ratio of 1.0/0.8.

\section{Materials and Methods}

\subsection{General Remarks}

Protein analysis by SDS-PAGE was performed using 15\% and 5\% acrylamide in the resolving and stacking gels, respectively. Gels were stained with Coomassie brilliant blue R-250 (Sigma-Aldrich). Electrophoresis was run under reducing conditions in the presence of $5 \% \beta$-mercaptoethanol. Pyruvate kinase (PK), lactate dehydrogenase (LDH), ATP, and 2-keto-D-gluconate (KG) were purchased from Sigma-Aldrich. 2-keto-3-deoxygluconate (KDG) was prepared as described by Lamble et al. [38] using a pyruvate aldolase from Sulfolobus solfataricus. 2-ketogulonate (KGul), 2-keto-3-deoxygulonate (KDGul), and 2-keto-D-galactonate (KGal) were prepared as described by de Berardinis et al. [37]. E. coli BL21(DE3) pLysS competent cells and pET28a expression vector were purchased from Invitrogen. Plasmid DNA purification kits were from Sigma-Aldrich. All other chemicals were purchased from Sigma-Aldrich as reagent grade.

\subsection{Methods}

${ }^{1} \mathrm{H}(400 \mathrm{MHz})$ and ${ }^{13} \mathrm{C}(100 \mathrm{MHz})$ nuclear magnetic resonance (NMR) analyses were carried out with a Bruker Avance $400 \mathrm{MHz}$ spectrometer. Mass spectra were recorded on a Q-exactive spectrometer from Thermos Scientific using an electrospray ionization (ESI).

\subsubsection{Cloning}

To amplify the kguK gene, chromosomal DNA from C. necator (R. eutropha) H16 (strain donated by Dr. Dieter Jendrossek, IMB, Univ. Stuttgart) was used. Primers for PCR with PwoI DNA polymerase were kguK-NdeI (5’ TTTTCATATGAGCACCGATCTTGACGTGG 3', engineered NdeI site underlined) and kguK-BamHI (5' TTTTGGATCCTCACAAACTGGCGGCCGC 3', engineered BamHI site underlined). The amplified DNA was cut with NdeI and BamHI and ligated to a likewise cut pBluescriptSK vector (Agilent Technologies). The ligation mixture was then used to transform E. coli DH5 $\alpha$ cells on LB-ampicillin plates (Amp $100 \mathrm{mg} / \mathrm{L}$ ) with X-Gal (blue-white selection). White colonies were analyzed for correct insertion. The $\mathrm{kg} u \mathrm{~K}$-containing NdeI-BamHI fragment was then cloned into a likewise cut pET28a(+) vector (Invitrogen) with selection for kanamycin resistance. The presence of the cloned gene was verified by custom DNA sequencing (GATC Biotech, Konstanz, Germany). 


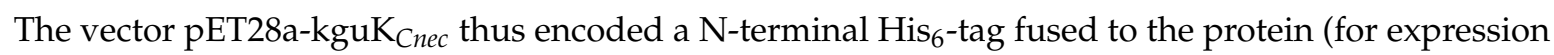
as N-terminally his-tagged protein in order to simplify its purification procedure by IMAC).

\subsubsection{Expression and Purification}

The gene expression was done in E. coli BL21(DE3) pLysS with induction by IPTG. Expression of $\mathrm{KGUK}_{\text {Cnec }}$ in BL21(DE3) pLysS cells was evaluated by SDS-PAGE. Colonies containing the plasmids

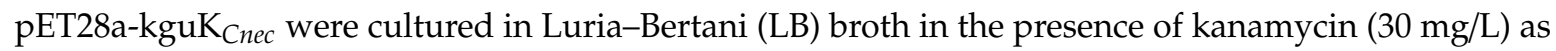
a selection antibiotic at $37^{\circ} \mathrm{C}$ under orbital shaking $(200 \mathrm{rpm})$. When the culture reached an $\mathrm{OD}_{600 \mathrm{~nm}}$ of 0.5 , protein expression was induced by adding IPTG ( $0.5 \mathrm{mM}$ final concentration), and the temperature was lowered to $30^{\circ} \mathrm{C}$. The culture was incubated for a further period of $12 \mathrm{~h}$. Cells were harvested by centrifugation, washed twice, and resuspended in buffer $\mathrm{A}\left(50 \mathrm{mM} \mathrm{NaH}_{2} \mathrm{PO}_{4}, 300 \mathrm{mM} \mathrm{NaCl}, \mathrm{pH}\right.$ 8.0). Cell suspension was disrupted by ultrasonication and the cell lysate was centrifuged at $10,000 \times g$ for $20 \mathrm{~min}$. Clear supernatant $(20 \mathrm{~mL})$ was loaded onto a $\mathrm{Ni}^{2+}$-NTA-agarose resin column (Qiagen, $\mathrm{h}=1.5 \mathrm{~cm} ; \varnothing=2.5 \mathrm{~cm}$ ) pre-equilibrated with buffer B (buffer A plus imidazole $20 \mathrm{mM}$ ). The column was washed with buffer $B$, and the retained proteins were eluted with the same buffer containing imidazole at a concentration of $250 \mathrm{mM}$. Eluted fractions containing pure protein were pooled together and directly stored at $4{ }^{\circ} \mathrm{C}$. In order to avoid possible interferences, imidazole was removed before each enzymatic experiment using a desalting column system (PD-10 sephadex G-25M columns, Pharmacia) pre-equilibrated with a buffer of $50 \mathrm{mM} \mathrm{NaH}_{2} \mathrm{PO}_{4}, \mathrm{pH} 8.0$ (final buffer). The imidazole removal was carried out just before each experiment by loading $2 \mathrm{~mL}$ of IMAC purified enzyme into the G-25M columns, equilibrated with the final buffer. The elution fractions containing the enzyme ( 2 or $3 \mathrm{~mL})$ were pooled together and its specific activity was assayed. No loss of activity was detected after the desalting procedure.

\subsubsection{Enzyme Activity Assays and Kinetic Studies}

Phosphorylation reactions involving different substrates catalyzed by KGUK were spectrophotometrically evaluated by measuring the release of ADP using a coupled assay with PK and LDH (Figure 7A) [39].

A typical assay was performed in a $1 \mathrm{~mL}$ reaction mixture containing Tris- $\mathrm{HCl}(25 \mathrm{mM}, \mathrm{pH} 8.0)$, $\mathrm{NADH}(0.2 \mathrm{mM}), \mathrm{ATP}(1.25 \mathrm{mM})$, phosphoenolpyruvate (PEP, $1.0 \mathrm{mM}), \mathrm{MgSO}_{4}(5.0 \mathrm{mM}), \mathrm{KCl}(50 \mathrm{mM})$, KGUK $_{\text {Cnec }}(2.0-10.0 \mu \mathrm{g}), \mathrm{PK}(3.3 \mathrm{U}), \mathrm{LDH}(2.3 \mathrm{U})$, and $1.25 \mathrm{mM}$ of KG. Similar activity assays were used to evaluate the $K_{G U K}$ Cnec specificity for different phosphate acceptors, where KG was replaced by the corresponding analyzed substrate. One unit of kinase activity was defined as the amount of enzyme able to produce 1 umole of 2-ketogluconate-6-phosphate (KGP) per min under the above conditions, using KG as the substrate.

Assays to determine kinetic parameters were performed following the kinase activity at different substrate concentrations under the general conditions described above. Steady-state kinetic assays for kinase activity were measured at $25{ }^{\circ} \mathrm{C}$ in a total volume of $1 \mathrm{~mL}$. Measurement of kinetic parameters for ATP was carried out with $2.1 \mu \mathrm{g} / \mathrm{mL}$ of purified $\mathrm{KGUK}_{\mathrm{Cnec}}$ and a constant excess of $\mathrm{Mg}^{2+}$ of $5 \mathrm{mM}$ in each assay point. KG was employed as the substrate $(1.25 \mathrm{mM})$, and, as the phosphate donor, 14 different concentrations of ATP were used (Figure 3A). To evaluate the effect of higher concentrations of ATP on the enzyme activity, additional assays were carried out at a $\mathrm{Mg}^{2+}$ concentration of $25 \mathrm{mM}$ to ensure the correct formation of the Mg-ATP complex (Figure 3B). In order to avoid ATP excess inhibition, the maximum ATP concentration used in assays for different phosphate acceptors was 1.25 $\mathrm{mM}$ in each kinetic point. Measurements of kinetic parameters for KG were performed with $2.5 \mu \mathrm{g} / \mathrm{mL}$ of purified $\mathrm{KGUK}_{\mathrm{Cnec}}$ at 15 different $\mathrm{KG}$ concentrations (Figure 2A). Assays to determine the kinetic parameters for KDG [38] were performed with $1.5 \mu \mathrm{g} / \mathrm{mL}$ of purified $\mathrm{KGUK}_{\mathrm{Cnec}}$ at 10 concentrations of the substrate (Figure 2B). Assays to determine the kinetic parameters for KGul and KDGul [37] were performed with $3.4 \mu \mathrm{g} / \mathrm{mL}$ of purified $\mathrm{KGUK}_{\text {Cnec }}$ at 9 and 11 concentrations of the respective substrate 
(Figure 2C and D). Kinetic constants were calculated using the built-in nonlinear regression tools in the software SigmaPlot 12.0 (Systat Software Inc).

3.2.4. Phosphorylation of 2-keto-D-gluconate.

Reaction Progress Monitoring

Phosphorylation reactions were followed by measuring the accumulation of pyruvate formed during the ATP regeneration process (pyruvate kinase/lactate dehydrogenase) using the spectrophotometric assay described above (enzyme activity, Figure 7A). Assays were performed in reaction mixtures of $1 \mathrm{~mL}$ containing the reaction aliquot Tris- $\mathrm{HCl}(40 \mathrm{mM}, \mathrm{pH} 8.0), \mathrm{NADH}(0.2 \mu$ mole), and LDH (2 U). One millimole of oxidized NADH was equivalent to 1 mmole of pyruvate, which was equivalent to 1 mmole of KGP formed.

Preparative Scale Synthesis and Purification of 2-ketogluconate-6-phosphate

The optimal KG/PEP ratio was established to be 1.0/0.8 (Figure 8), where the phosphate donor was the limiting substrate. Using these optimal conditions, KGP was synthesized at a 1.5 mmole scale. Reaction mixture composition was set as follows: Tris-HCl buffer $(104 \mathrm{~mL}, 50 \mathrm{mM}, \mathrm{pH}$ 8.0) containing PEP (1.5 mmole, $300 \mathrm{mg}), \mathrm{KG}(1.9 \mathrm{mmole}, 400 \mathrm{mg}), \mathrm{MgSO}_{4}(4 \mathrm{mM}), \mathrm{KCl}(40 \mathrm{mM}), \mathrm{KGUK}_{\text {Cnec }}(26.5 \mathrm{U})$, and PK (640 U). The reaction was initiated by addition of ATP (104 $\mu$ mole, which was 20 times less than the limiting substrate). After $12 \mathrm{~h}$ of incubation, $100 \%$ of PEP (the limiting substrate) was consumed, which indicated a KGP accumulation of 1.5 mmole in the reaction medium.

The reaction mixture was quenched by dropping the $\mathrm{pH}$ to 3 by adding $\mathrm{HCl}(5 \mathrm{M})$, resulting in partial precipitation of the enzymes. The $\mathrm{pH}$ was then adjusted to 6 by adding $\mathrm{NaOH}(5 \mathrm{M})$, and 2 eq of $\mathrm{BaCl}_{2}$ dihydrate were added. The solution was centrifuged at $10,000 \mathrm{rpm}$ at $4{ }^{\circ} \mathrm{C}$ for $10 \mathrm{~min}$ and the pellets were discarded. After partial concentration in vacuo, 5 volumes of ethanol were added. The solution was incubated overnight at $4{ }^{\circ} \mathrm{C}$ and then centrifuged. After one washing with ethanol followed by two other washings with acetone, KGP barium salt (molecular weight $476.5 \mathrm{~g} / \mathrm{mol}$ ) was recovered as a white powder in $85 \%$ yield $(1.275$ mmole, $0.608 \mathrm{~g})$.

\subsubsection{Analysis}

The sample existed under two cyclic forms: $\alpha$ and $\beta$ pyranoses, the latter being the major one. Due to an overlap of the signals, it was difficult to precisely quantify each form.

${ }^{1} \mathrm{H}$ NMR (400 MHz, deuterium oxide) $\delta 4.28(\mathrm{~d}, J=8.3 \mathrm{~Hz}, 1 \mathrm{H}, \mathrm{H} 3), 4.14(\mathrm{t}, J=8.3 \mathrm{~Hz}, 1 \mathrm{H}, \mathrm{H} 4)$, 4.05-3.83 (m, 3H, H5 + H6).

${ }^{13} \mathrm{C}$ NMR (101 MHz, deuterium oxide) $\delta 172.08(\beta \mathrm{p}, \mathrm{C} 1), 171.27(\alpha \mathrm{p}, \mathrm{C} 1), 103.38(\alpha \mathrm{p}, \mathrm{C} 2), 98.51$ $(\beta p, C 2), 82.21(\alpha p, C 3), 81.57(\mathrm{~d}, J=8.0 \mathrm{~Hz}, \alpha \mathrm{p}, \mathrm{C} 5), 79.55(\mathrm{~d}, J=8.4 \mathrm{~Hz}, \beta \mathrm{p}, \mathrm{C} 5), 77.89(\beta \mathrm{p}, \mathrm{C} 3), 75.42$ $(\alpha p, C 4), 73.58(\beta p, C 4) 65.64(\mathrm{~d}, J=5.1 \mathrm{~Hz}, \beta \mathrm{p}, \mathrm{C} 6), 65.23(\mathrm{~d}, J=4.6 \mathrm{~Hz}, \alpha \mathrm{p}, \mathrm{C} 6)$.

HRMS ESI-, $\mathrm{m} / \mathrm{z}$ calcd. for $\left[\mathrm{C}_{6} \mathrm{H}_{10} \mathrm{O}_{10} \mathrm{P}\right]=273.0012$; found 273.0022 . 
${ }^{1} \mathrm{H}$ NMR spectrum:

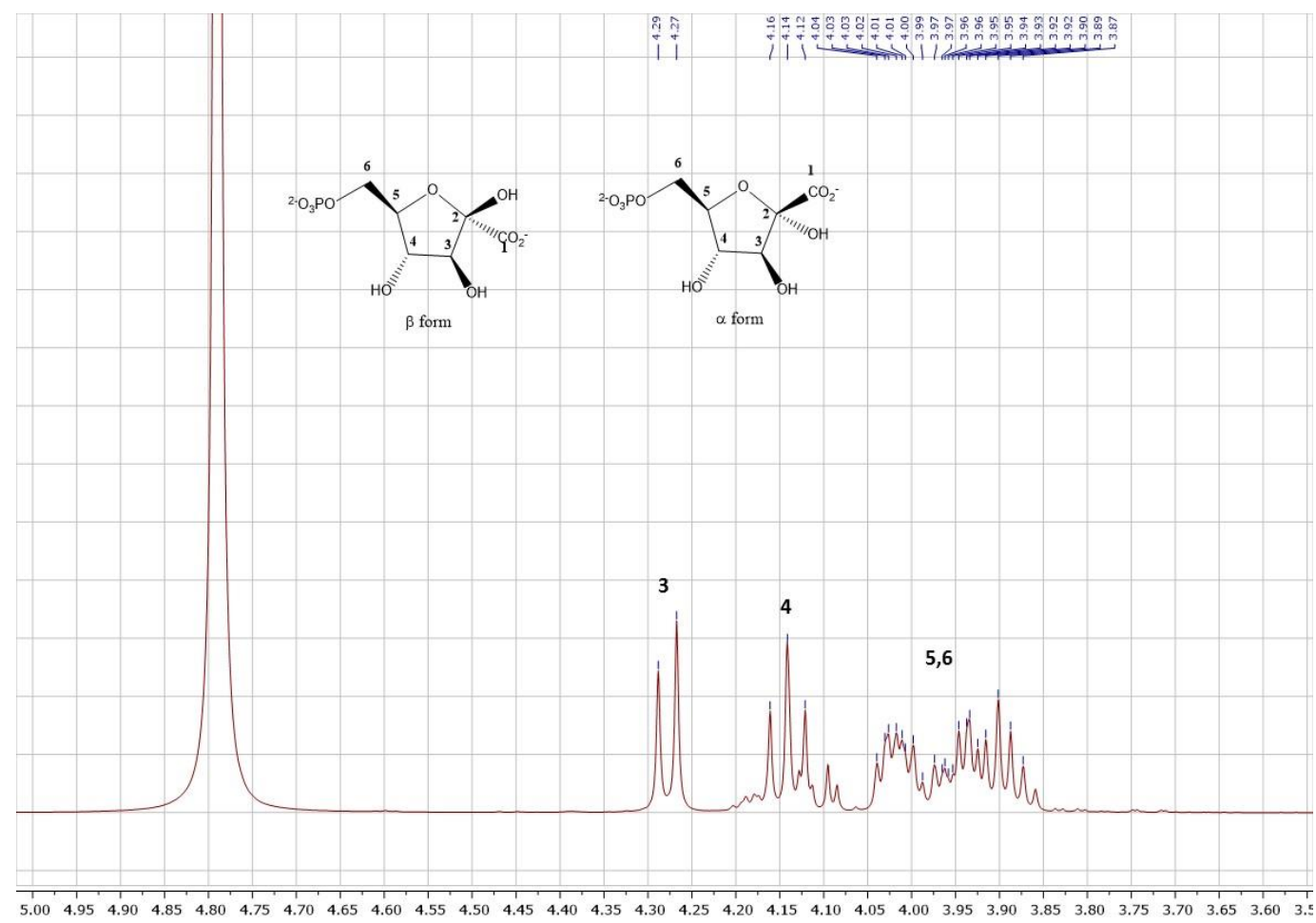

${ }^{13} \mathrm{C}$ NMR spectrum:

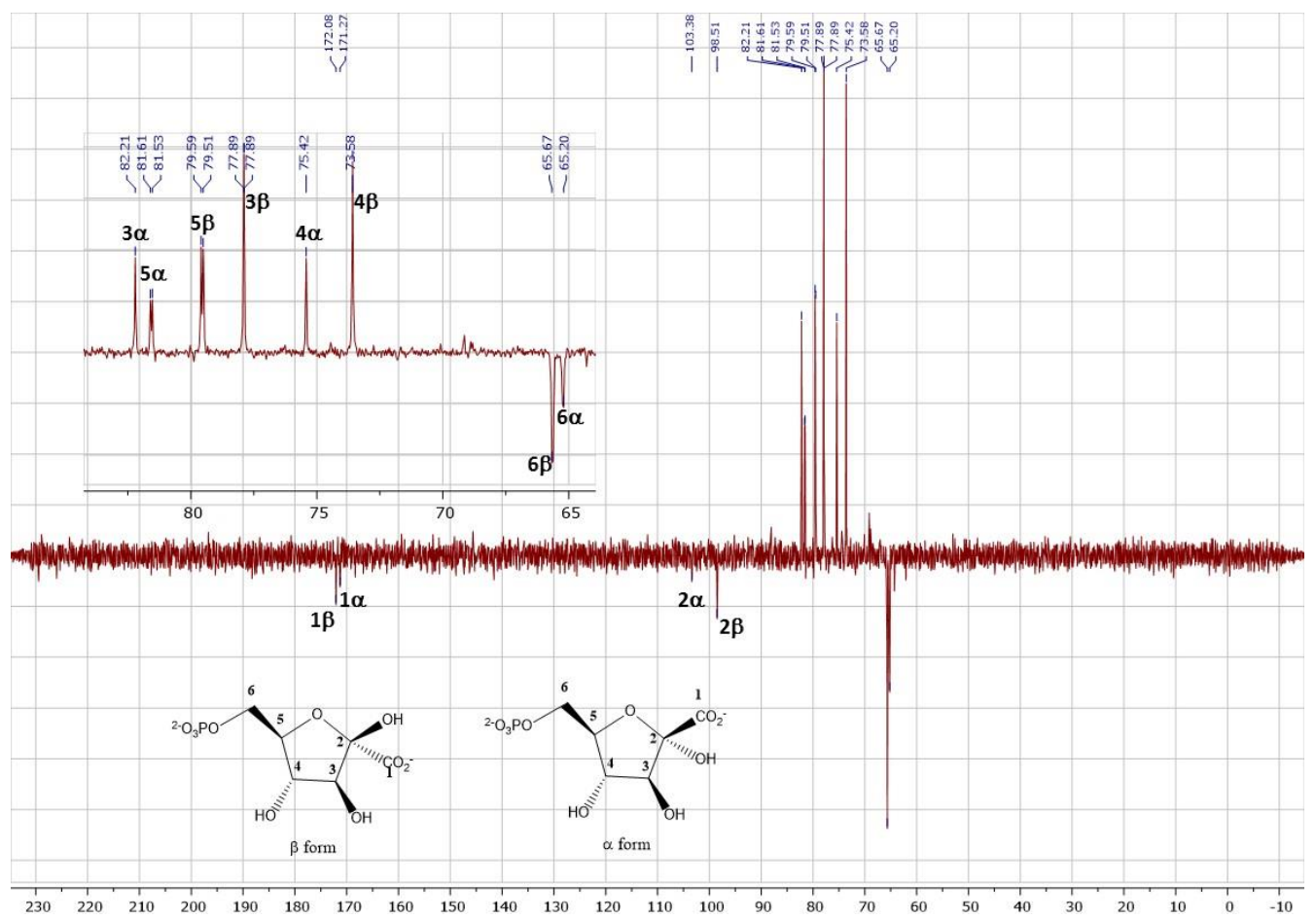




\section{Conclusions}

We successfully cloned, overexpressed, purified, and characterized KGUK from C. necator H16, which was first reported in 1974 but was never studied thereafter. This enzyme was found to be unstable in its pure form. We succeeded in stabilizing it by storage in an imidazole solution which was removed just before use. For the first time, we demonstrated that KDG is a substrate for this enzyme and that some KG and KDG epimers can also be converted into the corresponding phosphorylated derivatives. The ketoacid moiety was necessary since the complete set of keto or aldoses assayed were not found as substrates. Finally, KGP was successfully prepared at a preparative scale, with a good yield, and was fully characterized.

Author Contributions: conceptualization, V.H., M.L., C.G.-H., and G.A.S.; investigation, I.S.-M., N.T., and S.I.; resources, C.G.-H. and G.A.S.; writing-original draft preparation, I.S.-M., C.G.-H., and G.A.S.; writing-review and editing, all authors; supervision, C.G.-H. and G.A.S.

Funding: This research received no external funding. The ongoing support by Ministerium für Wissenschaft und Kunst, Baden-Württemberg (G.A.S.) and the Auvergne Council (C.G.-H., M.L. and V.H.) is acknowledged.

Acknowledgments: We thank Dieter Jendrossek for the gift of $C$. necator chromosomal DNA. We thank S. F. Royer for the generous gift of a pyruvate aldolase from Sulfolobus solfataricus.

Conflicts of Interest: The authors declare no conflict of interests.

\section{References}

1. Wen, L.; Huang, K.; Wei, M.; Meisner, J.; Liu, Y.; Garner, K.; Zang, L.; Wang, X.; Li, X.; Fang, J.; et al. Facile enzymatic synthesis of ketoses. Angew. Chem. Int. Ed. Engl. 2015, 54, 12654-12658. [CrossRef] [PubMed]

2. Wohlgemuth, R.; Liese, A.; Streit, W. Biocatalytic phosphorylations of metabolites: Past, present, and future. Trends Biotechnol. 2017, 35, 452-465. [CrossRef] [PubMed]

3. Vergne-Vaxelaire, C.; Mariage, A.; Petit, J.-L.; Fossey-Jouenne, A.; Guérard-Hélaine, C.; Darii, E.; Debard, A.; Nepert, S.; Pellouin, V.; Lemaire, M.; et al. Characterization of a thermotolerant ROK-type mannofructokinase from Streptococcus mitis: Application to the synthesis of phosphorylated sugars. Appl. Microbiol. Biotechnol. 2018, 102, 5569-5583. [CrossRef] [PubMed]

4. Fessner, W.-D.; Walter, C. "Artificial metabolisms” for the asymmetric one-pot synthesis of branched-chain saccharides. Angew. Chem. Int. Ed. Engl. 1992, 31, 614-616. [CrossRef]

5. Zimmermann, F.T.; Schneider, A.; Schörken, U.; Sprenger, G.A.; Fessner, W.-D. Efficient multi-enzymatic synthesis of d-xylulose 5-phosphate. Tetrahedron Asymmetry 1999, 10, 1643-1646. [CrossRef]

6. Ricca, E.; Brucher, B.; Schrittwieser, J.H. Multi-enzymatic cascade reactions: Overview and perspectives. Adv. Synth. Catal. 2011, 353, 2239-2262. [CrossRef]

7. Sánchez-Moreno, I.; Hélaine, V.; Poupard, N.; Charmantray, F.; Légeret, B.; Hecquet, L.; García-Junceda, E.; Wohlgemuth, R.; Guérard-Hélaine, C.; Lemaire, M. One-pot cascade reactions using fructose-6-phosphate aldolase: Efficient synthesis of D-arabinose 5-phosphate, D-fructose 6-phosphate and analogues. Adv. Synth. Catal. 2012, 354, 1725-1730. [CrossRef]

8. Guérard-Hélaine, C.; Debacker, M.; Clapés, P.; Szekrenyi, A.; Hélaine, V.; Lemaire, M. Efficient biocatalytic processes for highly valuable terminally phosphorylated C5 to C9 D -ketoses. Green Chem. 2014, 16, 1109-1113. [CrossRef]

9. Hélaine, V.; Mahdi, R.; Sudhir Babu, G.V.; De Berardinis, V.; Wohlgemuth, R.; Lemaire, M.; Guérard-Hélaine, C. Straightforward synthesis of terminally phosphorylated l-sugars via multienzymatic cascade reactions. Adv. Synth. Catal. 2015, 357, 1703-1708. [CrossRef]

10. Samland, A.K.; Rale, M.; Sprenger, G.A.; Fessner, W.-D. The transaldolase family: New synthetic opportunities from an ancient enzyme scaffold. ChemBioChem 2011, 12, 1454-1474. [CrossRef]

11. Schörken, U.; Sprenger, G.A. Thiamin-dependent enzymes as catalysts in chemoenzymatic syntheses. Biochim. Biophys. Acta (BBA) Protein Struct. Mol. Enzymol. 1998, 1385, 229-243. [CrossRef] 
12. Guérard, C.; Alphand, V.; Archelas, A.; Demuynck, C.; Hecquet, L.; Furstoss, R.; Bolte, J. Transketolase-mediated synthesis of 4-deoxy-d-fructose 6-phosphate by epoxide hydrolase-catalysed resolution of 1,1-diethoxy-3,4-epoxybutane. Eur. J. Org. Chem. 1999, 1999, 3399-3402. [CrossRef]

13. Shaeri, J.; Wright, I.; Rathbone, E.B.; Wohlgemuth, R.; Woodley, J.M. Characterization of enzymatic D-xylulose 5-phosphate synthesis. Biotechnol. Bioeng. 2008, 101, 761-767. [CrossRef] [PubMed]

14. Shaeri, J.; Wohlgemuth, R.; Woodley, J.M. Semiquantitative process screening for the biocatalytic synthesis of d-xylulose-5-phosphate. Org. Process. Res. Dev. 2006, 10, 605-610. [CrossRef]

15. Solovjeva, O.N.; Kochetov, G.A. Enzymatic synthesis of d-xylulose 5-phosphate from hydroxypyruvate and d-glyceraldehyde-3-phosphate. J. Mol. Catal. B Enzym. 2008, 54, 90-92. [CrossRef]

16. Charmantray, F.; Hélaine, V.; Legeret, B.; Hecquet, L. Preparative scale enzymatic synthesis of d-sedoheptulose-7-phosphate from $\beta$-hydroxypyruvate and d-ribose-5-phosphate. J. Mol. Catal. B Enzym. 2009, 57, 6-9. [CrossRef]

17. Guérard-Hélaine, C.; De Sousa Lopes Moreira, M.; Touisni, N.; Hecquet, L.; Lemaire, M.; Hélaine, V. Transketolase-aldolase symbiosis for the stereoselective preparation of aldoses and ketoses of biological interest. Adv. Synth. Catal. 2017, 359, 2061-2065. [CrossRef]

18. Trigalo, F.; Szabó, L. The synthesis of D-arabino-hexulosonic acid 6-phosphate and its stability in acid and alkaline medium. Eur. J. Biochem. 1972, 25, 336-340. [CrossRef]

19. Ciferri, O.; Blakley, E.R.; Simpson, F.J. Purification and properties of the 2-ketogluconokinase of Leuconostoc mesenteroides. Can. J. Microbiol. 1959, 5, 277-291. [CrossRef]

20. Swanson, B.L.; Hager, P.; Phibbs, P.; Ochsner, U.; Vasil, M.L.; Hamood, A.N. Characterization of the 2-ketogluconate utilization operon in Pseudomonas aeruginosa PAO1. Mol. Microbiol. 2000, 37, 561-573. [CrossRef]

21. Simons, J.A.; Teixeira de Mattos, M.J.; Neijssel, O.M. Aerobic 2-ketogluconate metabolism of Klebsiella pneumoniae NCTC 418 grown in chemostat culture. J. Gen. Microbiol. 1991, 137, 1479-1483. [CrossRef] [PubMed]

22. Yum, D.Y.; Lee, B.Y.; Hahm, D.H.; Pan, J.G. The yiaE gene, located at 80.1 minutes on the Escherichia coli chromosome, encodes a 2-ketoaldonate reductase. J. Bacteriol. 1998, 180, 5984-5988. [PubMed]

23. De Ley, J. Phospho-2-keto-D-gluconate, an intermediate in the carbohydrate metabolism of Aerobacter cloacae. Biochim. Biophys. Acta 1954, 13, 302. [CrossRef]

24. Narrod, S.A.; Wood, W.A. Carbohydrate oxidation by Pseudomonas fluorescens. V. Evidence for gluconokinase and 2-ketogluconokinase. J. Biol. Chem. 1956, 220, 45-55. [PubMed]

25. Frampton, E.W.; Wood, W.A. Purification and properties of 2-ketogluconokinase from Aerobacter aerogenes. J. Biol. Chem. 1961, 236, 2578-2580. [PubMed]

26. Vicente, M.; Cánovas, J.L. Glucolysis in Pseudomonas putida: Physiological role of alternative routes from the analysis of defective mutants. J. Bacteriol. 1973, 116, 908-914.

27. De Ley, J.; Vandamme, J. The metabolism of sodium 2-keto-d-gluconate by micro-organisms. Microbiology 1955, 12, 162-171. [CrossRef] [PubMed]

28. Roberts, B.K.; Midgley, M.; Dawes, E.A. The metabolism of 2-oxogluconate by Pseudomonas aeruginosa. J. Gen. Microbiol. 1973, 78, 319-329. [CrossRef]

29. Lessie, T.G.; Phibbs, P.V. Alternative pathways of carbohydrate utilization in pseudomonads. Annu. Rev. Microbiol. 1984, 38, 359-388. [CrossRef]

30. del Castillo, T.; Ramos, J.L.; Rodríguez-Herva, J.J.; Fuhrer, T.; Sauer, U.; Duque, E. Convergent peripheral pathways catalyze initial glucose catabolism in Pseudomonas putida: Genomic and flux analysis. J. Bacteriol. 2007, 189, 5142-5152. [CrossRef]

31. Nikel, P.I.; Chavarría, M.; Fuhrer, T.; Sauer, U.; de Lorenzo, V. Pseudomonas putida KT2440 strain metabolizes glucose through a cycle formed by enzymes of the entner-doudoroff, embden-meyerhof-parnas, and pentose phosphate pathways. J. Biol. Chem. 2015, 290, 25920-25932. [CrossRef] [PubMed]

32. De Ley, J. The phosphorylation of some carbohydrates, connected with the direct oxidation, by Aerobacter cloacae. Enzymologia 1953, 16, 99-104. [PubMed]

33. Nandadasa, H.G.; Andreesen, M.; Schlegel, H.G. The utilization of 2-ketogluconate by Hydrogenomonas eutropha H 16. Arch. Microbiol. 1974, 99, 15-23. [CrossRef] [PubMed] 
34. Pohlmann, A.; Fricke, W.F.; Reinecke, F.; Kusian, B.; Liesegang, H.; Cramm, R.; Eitinger, T.; Ewering, C.; Pötter, M.; Schwartz, E.; et al. Genome sequence of the bioplastic-producing "Knallgas" bacterium Ralstonia eutropha H16. Nat. Biotechnol. 2006, 24, 1257-1262. [CrossRef] [PubMed]

35. Ohshima, N.; Inagaki, E.; Yasuike, K.; Takio, K.; Tahirov, T.H. Structure of Thermus thermophilus 2-Keto-3-deoxygluconate kinase: Evidence for recognition of an open chain substrate. J. Mol. Biol. 2004, 340, 477-489. [CrossRef]

36. Ohshima, T.; Kawakami, R.; Kanai, Y.; Goda, S.; Sakuraba, H. Gene expression and characterization of 2-keto-3-deoxygluconate kinase, a key enzyme in the modified Entner-Doudoroff pathway of the aerobic and acidophilic hyperthermophile Sulfolobus tokodaii. Protein Expr. Purif. 2007, 54, 73-78. [CrossRef]

37. Berardinis, V.; De Guérard-Hélaine, C.; Darii, E.; Bastard, K.; Hélaine, V.; Mariage, A.; Petit, J.-L.; Poupard, N.; Sánchez-Moreno, I.; Stam, M.; et al. Expanding the reaction space of aldolases using hydroxypyruvate as a nucleophilic substrate. Green Chem. 2017, 19, 519-526. [CrossRef]

38. Lamble, H.J.; Danson, M.J.; Hough, D.W.; Bull, S.D. Engineering stereocontrol into an aldolase-catalysed reaction. Chem. Commun. 2005, 1, 124-126. [CrossRef]

39. Garland, P.B.; Randle, P.J. A Rapid enzymatic assay for glycerol. Nature 1962, 196, 987. [CrossRef]

Sample Availability: Samples of the compounds are available from the authors. 